Ann. Génét. Sél. anim., 1974, 6 (2), 253-266.

\title{
MANY-SIDED PROGENY TESTING OF BULLS ( $\left.{ }^{(}\right)$
}

\author{
K. MAIJALA \\ Agricultural Research Centre, \\ Institute of Animal Breeding \\ Tikkurila (Finland)
}

\section{SUMMARY}

Several arguments were given for acquiring many-sided information of the transmitting ability of A. I. bulls. Many traits can be measured on phenotypes, but progeny testing is still required in many cases. The present Finnish routine includes milk and fat yields, fat content and live weight of daughters. Field trials have been performed with regard to several additional traits :

Protein content and yield of milk. Ca. 4 6oo samples were tested for clearing up the possibility of testing bulls on the basis of one sample per daughter for protein content. There were large differences between laboratories and between herds in protein content. Heritability was 0.25 , whence a repeatability of 0.7 should be obtained with 35 daughters and samples, while in monthly testing I 70 samples are needed for the same accuracy.

Beef-producing ability. In slaughterhouse data from 21700 young animals, age accounted for 42 , herds 24 , areas 9 , breeds 3 and birth months 1.5 p. Ioo of the variance in carcass weight. Variation was wide even after correcting for age, sex, breed and area. Heritability was o.I 6 and 0.22 for 1 20-365 days old and 366-569 days old animals, resp. A total of 384 bulls were progeny tested on at least ro offspring.

Milkability of 6400 ist-calvers was evaluated by ranking them within herds in groups of three cows. Heritability was 0.08 , and 162 bulls were tested on at least Io daughters. Character, appetite and strength of estrus were ranked in the same interview trial. Heritabilities were 13 , 5 and 2 p. 100 , and 162 bulls were tested. Fertility, frequency of stillborn calves, occurrence of disease, abnormal calves and rheumatic leg symptoms have also been under study.

Milkability, calmness, appetite, estrus strength and carcass weight tests were positively correlated with growth performance test of sire. So were milk yield and live weight of daughters, while fat content was negatively correlated.

\section{INTRODUCTION}

Many-sided information of the genetic quality of A. I. bulls is highly desirable a. o. for the following reasons :

I. The potential influence of an individual bull is very great in the present era of frozen semen.

(1) Presented in the Study Meeting of E. A. A. P., Genetic Commission Verona, Oct. 9, I972. 
2. Both the efficiency and direction of genetic change depend on the information used as a basis for selection.

3. It is necessary to investigate the consequences of one-sided selection and to predict the possible unpleasant correlated responses.

4. It is valuable to prevent the gene losses on a rational way instead of at random, conserving all possible genes. Selection of e. $\mathrm{g}$. bull sires could be performed more resolutely, if the top bulls are known not to possess negative traits.

5. Different herd owners, areas or countries may have different goals and needs. Knowledge of all economically important traits of animals for sale is thus appreciated by importers.

6. Breeding goals may vary with time, because of changes in prices and other conditions. Semen deposited in semen banks should preferably have thorough ware descriptions.

7. It is important to know the faults of a bull, in order not to use it for a cow or herd with similar faults.

8. The breeders and their advicers pay in any case attention to various positive or negative traits of daughters. In order to lessen the effect of biassed judgments and rumors based on individual cases it is important to acquire objective information.

\section{PERFORMANCE TEST OR PROGENY TEST}

With regard to several traits the book-keeping concerning semen could be based on phenotypic measurements of bulls. As examples of such traits may be mentioned :

- growth rate (disadvantage : only one testing environment) :

- adult weight (maintenance feed requirements);

- feed conversion during growth ;

- carcass quality and leanness (ultrasonics or after slaughter) ;

- appetite and eating habits and preferences;

- male fertility (semen production traits, non-return rate) ;

- frequency of difficult calvings and stillbirths ;

- activity of various hormones, enzymes etc. in body fluids (studies concerning the usefulness of these need progeny tests).

Information of relatives as e. g. dams (milk yield, milkability, udders, longevity, health, character) could also be utilized, but complementary information of progeny is in many cases desirable a. o. for the following reasons :

I. Accurate evaluation needed because of economic importance of trait.

2. Heritability too low to give accurate performance test.

3. Trait measurable only on females.

4. Trait measurable only on slaughtered animals.

5. Great possibilities for selection after progeny testing.

6. Progeny testing possible without prolonging generation interval too much.

7. Clearing up the usefulness of performance tests presupposes progeny tests.

For routine purposes it is necessary to weigh the costs of progeny testing against the value of the additional information obtained, but by searching for simplified 
methods for progeny testing this might become economically feasible and still sufficiently accurate for a greater number of traits than is usual to-day. The number of daughters included as well as the number and accuracy of measurements per daughter can be adjusted according to the economic importance and heritability of each trait. The main data sources available are : milk-recording, A. I. statistics, veterinary statistics, slaughter statistics, special collection by breeding advicers, and testing stations.

\section{PRESENT PROGENY TESTING ROUTINE IN FINLAND}

The present system is based on 12 months' records of milk and fat. Until 1972 the results were computed only for the official operational year (June I-May 3I), but now rolling I2-month records are also utilized. These make it possible to renew the tests every month if desired. A daughter is included as soon as she has milked I2 months after her Ist calving and kept with until she has milked three years. The following traits are included at present :

I. Relative milk deviation $=$ average deviation of relative milk yield ( $\mathrm{p}$. Ioo) from the corresponding age average of the breed (corrected for month of calving and number of daughters).

2. Relative fat yield deviation as for milk.

3. Relative fat corrected (4 p. IOO) milk deviation as for milk.

4. Fat content deviation from herd average (age-corrected).

5. Simple index $=(\mathrm{I})+$ Io (4). in $\mathrm{kgs})$.

6. Live weight deviation $=$ estimated live wt. - herd average (age-corrected,

Measuring the milk yield per unit time and including even 2 nd and 3 rd records make the test more many-sided than tests based on 305-day lactation yields. It is especially safer with regard to fertility, since prolonged calving intervals tend to lower annual yields, while the 305-day yields favour repeat breeders. Very little daughters are needed to compensate the loss in basic $h^{2}$ caused by our way of measuring the yield.

A disadvantage in the live weight deviation is that the measures (body length and chest girth) are taken at varying stages of lactation. This harm is reduced with the increase of group size, and an $r=0.35$ between 365-day weight of bull in performance test and daughters' live weight deviation ( $n=136$, Ayrshire) seems to indicate that the latter gives a useful picture of the adult size and maintenance requirements of daughters. Its value in evaluating beef production ability is somewhat doubtful, since the growth for beef should take place before the age of I-I.5 yrs. In fact, one should require about I p. Ioo unit increase in the relative milk deviation for each ro $\mathrm{kg}$ increase in the live weight deviation. Considering the value of calf for beef production this requirement could be halved to $0.5 \mathrm{p}$. roo units. In a sample of ca. 200 progeny-tested Ayrshire bulls the milk deviation increased by 0.2 p. roo units per ro $\mathrm{kg}$ increase in live weight. 


\section{EXPERIMENTAL PROGENY TESTING}

\section{FOR PROTEIN CONTENT}

Because of the increased actuality of including protein content among the grounds of milk payment and among the breeding goals, a field trial concerning about 4600 milk samples was performed in July-September, I97I. The purpose was to clear up the possibilities of progeny testing bulls on the basis of one sample per daughter (Ist-calvers) and to get actual progeny tests for a year class of bulls.

The samples collected in July were analyzed with Promilk and Milkotester in laboratory I, and those from September with IRMA in laboratory II. The preservative in use was not always properly dissolved in July and many samples were kept in room temperature rather long time, and hence a proportion of samples was unsuitable or gave biassed results, especially for fat content. The useful part of data comprised ca. 4.000 cows. Information was available also of the test-day milk yield and of the fat content of the same day determined in the milk-recording with the Gerber-method. The relative importance of some external causes of variance is shown in table $r$.

TABLE I

The relative components of variance in milk composition due to some systematic factors

Composantes de la variance de la composition du lait dues à quelques facteurs systématiques

\begin{tabular}{|c|c|c|c|c|c|c|}
\hline \multirow{3}{*}{ Source of variance } & \multicolumn{6}{|c|}{ Variance component $(\%)$} \\
\hline & \multicolumn{3}{|c|}{ Laboratory } & \multicolumn{3}{|c|}{ Milk-recording } \\
\hline & $\begin{array}{c}\text { Protein } \\
(\%)\end{array}$ & $\begin{array}{l}\text { Fat } \\
(\%)\end{array}$ & Prot./fat & $\begin{array}{l}\text { Fat } \\
(\%)\end{array}$ & $\begin{array}{l}\text { Milk } \\
(\mathrm{kg})\end{array}$ & $\begin{array}{c}\text { Days from } \\
\text { calving }\end{array}$ \\
\hline 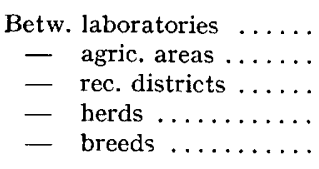 & $\begin{array}{c}53.9^{*} \\
0.9^{*} \\
2.3 \\
16.9^{*} \\
0.0\end{array}$ & $\begin{array}{l}3.1^{*} \\
2.6^{*} \\
0.0 \\
40.5^{*} \\
2.9^{*}\end{array}$ & $\begin{array}{c}19.1^{*} \\
2.1^{*} \\
0.0 \\
33.4^{*} \\
2.1^{*}\end{array}$ & $\begin{array}{c}5.5^{*} \\
1.1^{*} \\
2.8 \\
21.3^{*} \\
6.9^{*}\end{array}$ & $\begin{array}{c}18.3^{*} \\
2.2^{*} \\
0.0 \\
30.9^{*} \\
8.6^{*}\end{array}$ & $\begin{array}{c}37.4^{*} \\
1.8^{*} \\
0.6 \\
12.2^{*} \\
0.0\end{array}$ \\
\hline$*: P<0.001$ & & & & & & \\
\hline
\end{tabular}

The figures are based on hierarchical analyses of variance, but the significances agree to great extent with the results of least-squares analysis. The great importance of laboratories is mainly due to the incomplete calibration of IRMA in laboratory II. The difference in protein content between laboratories was as high as 0.44 p. Ioo 
units according to least-squares constants, even though the differences in time from calving were eliminated. It thus seems necessary to correct the probable differences between laboratories or analyzer types in handling milk composition data.

The large herd components do not cause great problems in progeny testing in case the daughters are located in tens of herds. A part of the herd differences could be explained by herd averages for milk yield and fat content of the recording year. The regressions of all composition traits on these averages were significant in the LS-analyses. Both fat determinations decreased by $0.05 \mathrm{p}$. Ioo and protein content increased by 0.02 p. Ioo per $\mathrm{I}$ ooo $\mathrm{kg}$ increase in herd average. P/F-ratio increased by I.4 p. IOo. An increase of herd fat p. Ioo by I p. Ioo was followed by 0.45 p. IOo (lab.) and 0.59 p. Ioo (rec.) increase in fat content, 0.17 p. Ioo increase in protein content and $4.7 \mathrm{p}$. Ioo decrease in $\mathrm{P} / \mathrm{F}$-ratio.

An increase of the time from calving to sampling by roo days increased both fat contents by $0.26 \mathrm{p}$. Ioo and protein content by $0.19 \mathrm{p}$. Ioo while $\mathrm{P} / \mathrm{F}$-ratio decreased insignificantly.

The differences between sires in the corrected (lab., areas, breeds, herd averages for milk and fat-p. roo, time from calving) values were highly significant for all composition traits, and the $h^{2}$-estimates were $0.25,0.32,0.36$ and 0.28 , resp., for protein-p. Ioo, lab.- fat-p. Ioo, rec.-fat-p. Ioo and P/F-ratio. The estimates were similar for both laboratories, so the incomplete calibration of IRMA did not affect the accuracy. The lower $h^{2}$ for lab.-fat-p. Ioo as compared to rec.-fat-p. Ioo is explained by the improper dissolving and long conservation of some samples.

A total of 144 bulls were tested on at least ro daughters. The range within Ayrshire (II4) was about I p. Ioo unit for fat-p. IOO, 0.7 p. Ioo for protein and 20 p. IOO for $\mathrm{P} / \mathrm{F}$-ratio. The correlation between the two fat-p. roo averages was 0.36 , and the correlation of these with protein-p. Ioo $0.3 \mathrm{I}(\mathrm{lab})$ and 0.42 (rec.). On the basis of the $h^{2}$-estimates a repeatability of 0.70 should be obtained with 35 daughters for protein p. Ioo, when there is only one sample per daughter. On the basis of ro samples a year the corresponding number is $17\left(h^{2}=0.5\right)$, i. e. I70 samples vs. 35 samples for the same accuracy.

\section{EXPERIENCES OF FIELD PROGENY TESTING FOR BEEF PRODUCTION}

Because of the availability of performance testing, progeny testing can be considered unnecessary for evaluation of bulls for beef producing ability. At the present state of knowledge, however, extensive progeny tests are needed merely for clearing up whether this conclusion is justified. It would be valuable to know (I) how the growth results obtained in an experimental environment are reflected in offspring reared in various practical conditions (2) whether the carcass quality of the offspring of well-grown bulls is satisfactory, and (3) how the progeny tests for milk and beef are correlated with each other.

In case progeny testing could be made simple and cheap enough, it might be well-founded to check the results of performance test also regularly. The usefulness 
of slaughter house data, reported by milk-recorders on optical forms since $\mathrm{x} 968$, and the possibility of developing a method for progeny testing, have been studied on the basis of 2 I 700 animals. In over $98 \mathrm{p}$. IOO of the cases the age at slaughter was between 90 and 600 days, with rather normal variability and an average of 3 II days. Carcass weights varied from ro to $260 \mathrm{~kg}$, and the mean was I $4 \mathrm{~kg}$. $3 / 4$ of the animals were males. An increase of one day in slaughter age increased carcass weights by 3 I 9 , 310 and 238 grams in the age groups $120-269,270-389$ and 390-569 days, respectively.

Differences between age groups, herds, areas, breeds and birth months explained 42 p. IOO, 24 p. IOO, 9 p. IOO, 3 p. IOO and I.5 p. IOO, resp., of the variance in carcass weights. The variation of these was surprisingly wide even after elimination of age, sex, breed and area differences : for $120-365$ days old animals the 9-month weights varied from 40 to $180 \mathrm{kgs}$ in Ayrshire and from 35 to I70 $\mathrm{kg}$ in Finncattle. For 366 569 days old animals the range at 14.5 months was ca. $150 \mathrm{~kg}$. Thus the feeding of calves for beef is unsatisfactory in many herds. The range of herd means of at least 3 animals was IIo $\mathrm{kg}$ at 9 months, and the extreme differences between areas were $20-30 \mathrm{~kg}$ in age-corrected weights. At the performance testing station the average weight of Ayrshire bulls at 365 days was $450 \mathrm{~kg}$ in $\mathrm{I} 97 \mathrm{I}$, which means a carcass weight of over $230 \mathrm{~kg}$. The C. V. of 270 -day weights at the station has been less than Io $\mathrm{p}$. Ioo, while that of corrected carcass weights of I20-365-days old animals at 9 months was $2 \mathrm{I}$ p. IOO.

The average $h^{2}$-estimates for corrected carcass weights were $16 \mathrm{p}$. IOo and $22 \mathrm{p}$. Ioo, resp., for I20-365-days old (I I435) and 366-569-days (38I3) old animals. Assuming an $h^{2}=0.2$, a repeatability of 0.7 in progeny testing would be obtained with 44 offspring and $b=0.5$ with 20. A total of 274 Ayrshire and rio Finncattle bulls were tested on at least Io offspring. The averages at 9 months varied from 83 to II 5 $\mathrm{kg}$ in Ayrshire and from 77 to $106 \mathrm{~kg}$ in Finncattle. An attempt to utilize relative carcass weights (comparisons to herd means) decreased the number of tested bulls by $79 \mathrm{p}$. Ioo and the group size of the remaining bulls by $7 \mathrm{I}$ p. IOo. Thus, the relative tests have to be abandoned, especially since the offspring of selected bulls compete with each other in the most interested herds. On the other hand, the confounding of feeding intensity and interest to top bulls lessens the value of the absolute tests. This bias is shown e. $\mathrm{g}$. by the fact that the corrected carcass weight of 345 Charolais $\times$ Ayrshire crosses was 23 p. Ioo above Ayrshire mean, while the difference in our experiments has been only $9 \mathrm{p}$. Ioo.

During the last years we have tried to build a network of big specialized herds which are rearing calves mediated by slaughter houses and which are interested in collaboration. In these ca. 50 herds comparisons can be performed within herds, and the disturbing effect of correlation between feeding and genetic quality can be eliminated.

\section{AN INTERVIEW TRIAL CONCERNING MILIABILITY}

The increased costs of human labor have made it is necessary to pay increasing attention to milkability, especially in large herds. In Finland, the interest in this trait has grown rather slowly because of the small herd sizes and since one cannot 
strive for extremely easy milking (risk of mastitis and milk leak). A hypothesis can also be made that the slowly milking daughter groups cannot compete with regard to relative milk yields in the hasty milking routine. This hypothesis may not, however, entirely hold in small herds.

In order to get a large number of bulls progeny-tested cheaply and rapidly, an interview method was given a trial in 1972 . The milk-recorders interviewed the herd managers concerning the ranking of the last three Ist-calvers within the herds. By placing in each herd one cow to each possible rank (6, 2 and 3), one hoped to avoid the usual disadvantage of subjective evaluation, that different judges utilize different parts of the scale and that only very limited part of scale is utilized. The judgment would be based on experiences during tens of milkings, and the computations would be simple, without various corrections. Collecting the data on optical forms made their handling easy and rapid.

Useful data were obtained of 6426 cows. The effect of time from parturition was only 0.25 p. Ioo of variance. Heritability was ca. 0.08 . The result can be considered encouraging, for the instructions did not go to the milk-recorders properly, due to short time and many intermediaries. A total of 162 bulls had at least Io daughters. Ca. 20 p. Ioo of the bulls differed more than 0.2 rank points from 2.0 to both directions, and the extremes were +0.55 and -0.64 . For those few bulls which had previously been tested with special equipment, the results were in reasonable agreement. More can be said after the results of a simultaneous trial on measuring milking time have been analyzed.

\section{INTERVIEW TRIAL ON CHARACTER,}

\section{APPE'TITE AND ESTRUS SYMPTOMS}

In connection with the interview trial on milkability, similar information was collected on the character (calmness), appetite and estrus symptoms of firs-calvers. The $h^{2}$-estimates were respectively I 3 p. Ioo, 5 p. Ioo and 2 p. Ioo. Exactly the same bulls were tested as for milkability, and the variation was of course similar.

\section{PROGENY-TESTS FOR FERTILITY}

In the I960's extensive statistical analyses were performed by MAIJALA (I964, I966) on the genetic variation of various fertility traits in practice. The $h^{2}$-estimates varied according to the measure used, the age of cow, the A. I. unit, year and the source of information, but the most common values were $\mathrm{I}-3 \mathrm{p}$. Ioo. By utilizing repeated measurements on the same cows it was possible to judge individual cows with an accuracy of $6 \mathrm{p}$. Ioo at $3 \mathrm{rd}$ calving. On the basis of these estimates it was possible to calculate that $a b=0.7$ in progeny tests should be obtained with 300 daugters for several fertility traits. This number is easily attained in A. I., but the basic $h^{2}$ tended to decline, when one came to larger progeny groups (selected sires), and 
hence it seemed difficult to reach a repeatability of 0.5 in practice. It is very important to eliminate the most important external factors, since even a small increase in $h^{2}$ at the vicinity of zero decreases considerably the requirements concerning number of daughters. For some fertility traits, as e. g. non-return rate, the test can be performed on heifers, so that the generation interval does not suffer.

It is not yet clear, however, whether the heifer fertility is genetically related to cow fertility. There are some signs of that it is a question of partly different traits. It is likely that progeny test for fertility will be made a routine. For research purposes one tries to progeny test bulls for the frequency of multiple births, in order to see the possibilities of increasing the calf crop for beef production by genetic means.

\section{FREQUENCY OF STILLBORN CALVES}

LINDSTRÖM (I970) has given the average frequency of stillborn calves for 43 Ayrshire bulls in I $969 / 70$. The minimum number of births for adult dams was 200 and for heifer dams roo. In the former case the frequencies varied from 0.69 to 7.08 p. IOo and in the latter from I.I3 to $6.52 \mathrm{p}$. Ioo. The correlation between the two series of values was 0.I7.

\section{EXPERIMENTAL COLLECTION OF DISEASE DATA}

A trial was arranged in $197 \mathrm{I} / 72$ to collect information for progeny tests of the most important diseases. The veterinarians should have made a note of each treatment with a special code to a card in the herd, and the milk-recorders should have reported these notations on optical forms. The necessary information of descendance, age etc. would then have been found from the EDP-registers. The frequency of veterinarians carrying out the notations was rather low, however, and it appeared difficult to perform any statistical analyses. Some individual veterinarians are interested in the matter, and the work may be continued with them. In the case of promising results the circle could be expanded gradually, especially if those participating would regularly get surveys and reports based on the data. The experiences obtained in Germany (GRAVERT and SchRÖDER, I972) do not give very much promise.

\section{ABNORMAL, CALVES (SO-CALLED LETHALS)}

In the first part of the I960's attempts were made to collect information of abnormal calves. Special forms were planned for reporting these, and the A.I. technicians were asked to send the calves to the Veterinary College for diagnosis. Ca. 200 cards were received annually, but it was difficult to draw any conclusions concerning lethal carriers. The symptoms were very vague and variable in most 
cases, and in the few cases they were clear one could not be sure about the paternage. Some cases were reported for most of the bulls. It became obvious that most of the abnormalities were caused by environmental factors. Since there are many more important traits and tasks in cattle breeding, the work on abnormalities has been almost discontinued.

\section{A COUPLE OF TRAITS CONSIDERED FOR PROGENY TESTING}

There has been some thought to measure the persistency of lactation on the basis of monthly milk recordings, available in EDP-registers. For example, the coefficient of variation of daily yields could be computed according to BRUUN (I928). The importance of persistency has recently increased in Finland, because of the restrictions of oil concentrate importation and of the expansion of green silage feeding. Another trait of actual interest is the paresislike leg fault which occurs in some families of bulls and which is claimed to occur also in females.

\section{SOME CORRELATIONS BETWEEN PROGENY TESTS}

\section{FOR DIFFERENT TRAITS}

One of the main motives for many-sided progeny-tests has been to get possibilities for elucidating the possible consequences of one-sided breeding for milk. Preliminary estimates of correlations between some traits are shown in table 2 .

In spite of the small numbers of bulls in most of the comparisons, some significant correlations were observed. The milk values, for example, were negatively correlated with fat-p. IOO and protein-p. IOO, but positively with carcass weight of progeny in the field. The last-mentioned correlation is obviously biassed, however, since the most advanced herds have been mostly interested in the top milk bulls.

The routine fat-p. Ioo test was naturally positively correlated with both trial tests and also with the protein-p. Ioo, and the trial tests were correlated with each other. It is interesting to observe that the live weight deviation of daughters was clearly correlated with the carcass weight of young slaughter offspring $(r=0.3 \mathrm{I})$, even with the relative weight (0.29). Its correlation with milk deviation was insignificant 0.14 , but about similar values have been obtained from bigger materials. The positive correlation between protein-p. Ioo and appetite is also interesting, although far-reaching conclusions cannot yet be drawn. The positive correlations among milkability, appetite and estrus symptoms may partly be caused by biassed judgment, since they were judged simultaneously on the same optical form. The herd manager may have been inclined to give the same rank for the same cow for several traits.

In earlier studies of MAIJALA (I966) various fertility traits were slightly negatively correlated with progeny tests for milk. The magnitude and even the sign of the correlation varied with the measures used for both milk and fertility, as well as with the age class in question. The antagonism is most obvious during the rst lactation, if milk yield is measured per year and not per lactation. 


\section{CORRELATIONS OF PROGENY TESTS WITH PERFORMANCE TEST}

The necessity of progeny testing for various traits and the possibilities to intensive selection of bulls on the basis of performance test depend partly on whether there are antagonisms between traits which can be judged on the bull itself in a given test environment and those measured on progeny in varying environments. Preliminary results concerning these relationships are presented in figures I and 2 . In figure I the correlations are positive with almost no exception. The correlations of

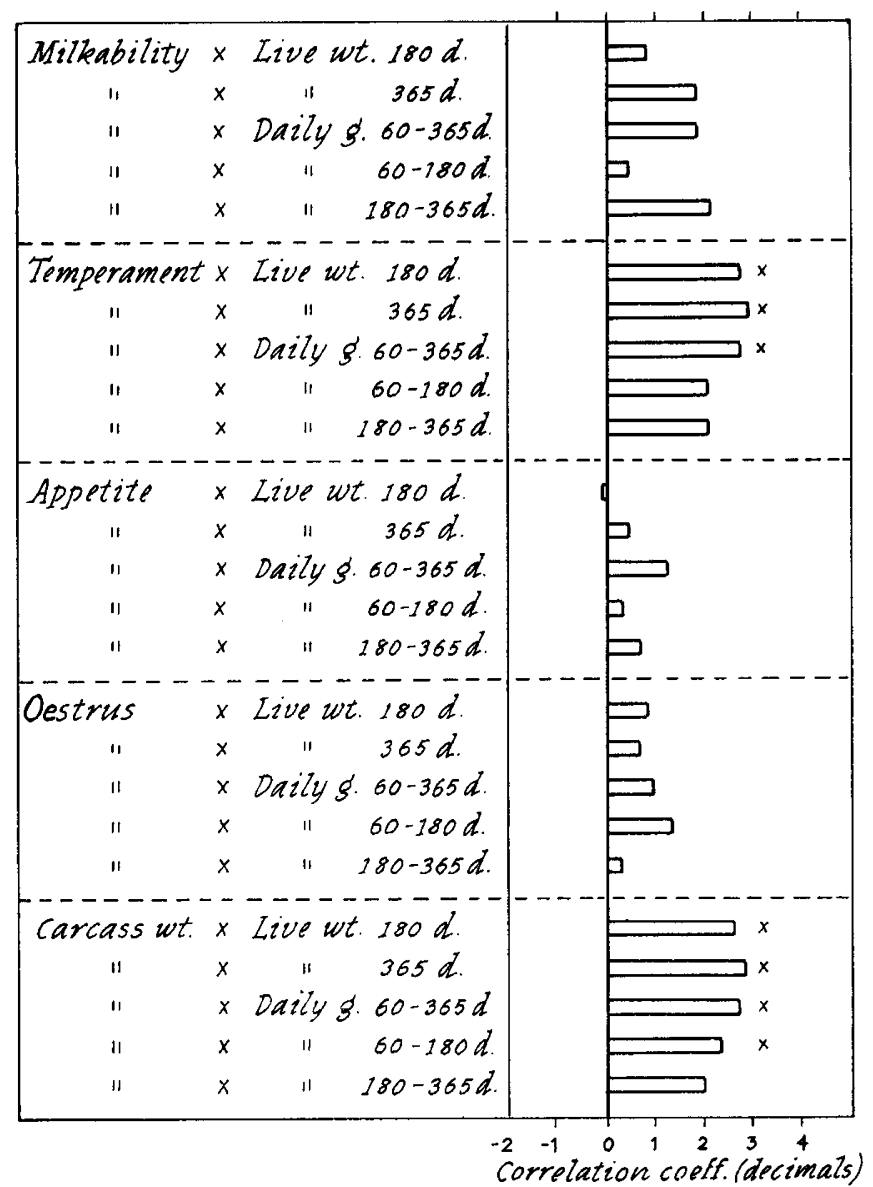

FIG. I. - Correlations between progeny tests for some traits and performance tests of the same bulls 60 Ayrshire bulls in the first four traits and 68 Ayrshire bulls in the carcass weight. Progeny tests based on at least ro offspring. * : significantly different from zero

FIG. I. - Corrélations entre tests sur descendance pour quelques traits et performance test des mêmes taureaux 60 mâles Ayshire pour les 4 premiers traits et 68 taureaux Ayshire pour le poids de carcasse.

Test sur descendance d'au moins dix enfants.

* : significativement différent de zéro 
carcass weight show that the data from field are useful and that the growth results obtained in the specific test environment are reflected in the growth of progeny in varying conditions. Surprisingly, the calmness of daughters was as closely correlated with the growth rate of bull as was the carcass weight of offspring. A calm temperament may thus be an important presupposition for rapid growth and it appears to be an inheritable trait, even from sire to daughters.

From figure 2 appears that the live weight measured on milking daughters is similarly correlated with a bull's own growth as the carcass weight of his young slaughter offspring ( $75 \mathrm{p}$. Ioo males). The most surprising observation was the antagonism between bull's growth rate at testing station and his daughters' fat content.

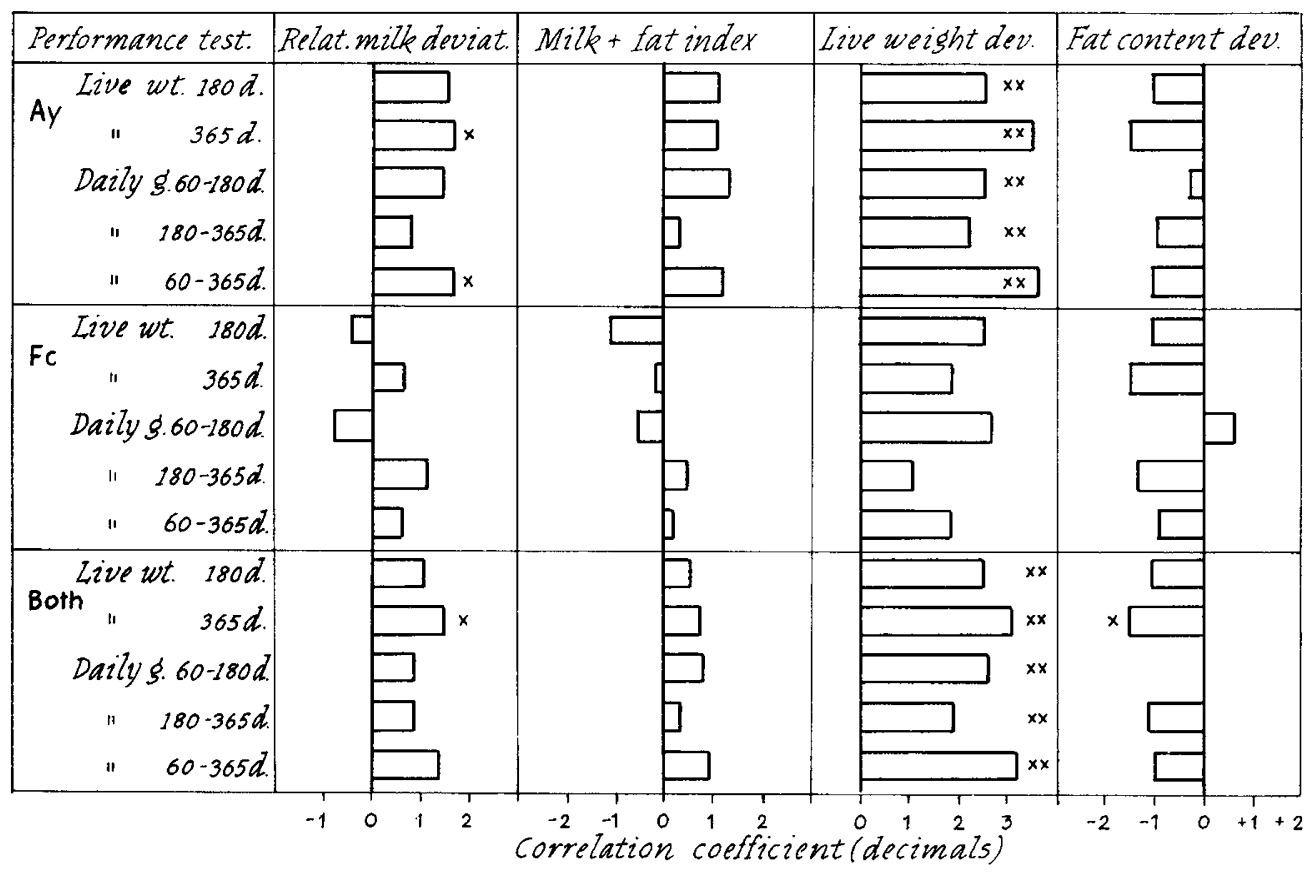

FIG. 2. - Correlations of performance test results with progeny-tests for milk, milk + fat, index live weight and fat content

I36 Ayshire bulls and 47 Finncattle bulls tested in 1972

* : significant $(\mathrm{P}<0.05) ; \quad * *$ : highly significant $(\mathrm{P}<\mathrm{o.oI})$

FIG. 2. - Corrélations des résultats de performance test avec ceux du test sur la descendance pour le lait, l'index laitier et beurrier, le poids vif et la matière grasse

I 36 taureaux Ayshire et 47 taureaux Finnois testés en 1972

* : significatif $(\mathrm{P}<0,05) ; \quad * *$ : hautement significatif

This could be explained so that families which prefer to convert energy to fat cannot compete successfully in growth. This negative association made also the correlation of milk + fat index with performance test lower than that of milk yield. Both of these correlations are partly caused by the bigger size of daughters of well-grown sires. 


\section{NECESSITY TO CONSTRUC'T AN INDEX}

Many-sided information of bulls and their offspring leads easily to harmful confusion in selection, thus slowering the genetic progress with regard to the main breeding goals. A proper weighting of different traits according to their economic importance, the accuracy of evaluation and interrelationships among them is therefore important. For the main selection decisions it is necessary to construct a selection index incorporating all the information to one figure, but the breeders have to know also the special good and bad points of each bull. Some traits which are positively correlated with the main traits can be left unmeasured and unconsidered, but their inclusion could in some cases also increase the judging accuracy and thus the rate of progress.

Reçu pour publication en mai 1974.

\section{RÉSUMÉ}

\section{LE TESTAGE A MULTIPLES FINS DES TAUREAUX SUR DESCENDANCE}

La discussion a porté sur la nécessité de réunir une information exhaustive sur les caractéristiques génétiques des taureaux d'insémination artificielle. Plusieurs caractères peuvent être mesurés sur l'individu mais le testage sur descendance est encore nécessaire dans beaucoup de cas. Le système finlandais actuel prend en compte les productions de lait et de matière grasse, le taux butyreux, et le poids vif des filles. Des enquêtes en ferme portant sur plusieurs autres caractères ont été effectuées.

\section{- Production de matière protéique et taux de protéine dans le lait.}

Environ ${ }_{4} 600$ échantillons ont été analysés afin de tester la possibilité d'un testage des taureaux sur la base d'un seul échantillon par fille pour le taux de protéine. De grandes différences entre laboratoires et entre troupeaux ont été mises en évidence.

L'héritabilité était égale à 0,25 . Une répétabilité de 0,7 serait donc obtenue avec 35 filles ou échantillons tandis que dans le contrôle laitier mensuel il faut 170 échantillons pour la même précision.

\section{- Production de viande.}

D'après 21700 résultats obtenus en abattoir sur de jeunes animaux, l'âge, le troupeau, la zone d'origine, la race et le mois de naissance rendent compte respectivement de 42, 24, 9, 3 et I,5 p. Ioo de la variance du poids de carcasse.

La variation était importante même après correction pour l'âge, le sexe, la race et la zone. L'héritabilité à I 20-365 jours et 366-569 jours était de 0,16 et 0,22 respectivement. Un total de 384 taureaux ont été testés sur au moins io descendants.

\section{- Aptitude à la traite.}

L'aptitude à la traite de 6400 génisses a été évaluée par leur rang dans un groupe de trois vaches du troupeau. L'héritabilité était de 0,08 et 162 taureaux ont été testés sur au moins ro filles. Le caractère, l'appétit et l'intensité de l'œstrus ont été évalués par la même méthode. L'héritabilité était de 13,5 et 2 p. IOO; I62 taureaux ont été testés. La fertilité, la fréquence de veaux mort-nés, la susceptibilité aux maladies, l'apparition de veaux anormaux ont été aussi étudiés. 
L'aptitude à la traite, la placidité, l'appétit, l'intensité de l'œstrus et le poids de carcasse ont été en liaison positive avec les performances de croissance du taureau. Il en a été de même pour la production laitière et le poids vif des filles tandis que le taux butyreux était en corrélation négative.

\section{REFERENCES}

BRUUN E., 1928. Summary : Factors influencing the lactation curve and the hereditariness of its shape in East-Finnish cattle. (Otherwise in Finnish). Valt. Maatal. koetoim. julk., 18, I-r37.

Gravert H. O., Schröder E., I972. Erhebungen über tierärztliche Hilfe bei Milchkühen. Züchtungskunde, 44, 75-80.

Lindström U., 1970. The frequency of stillborn calves in cattle breeds in Finland (In Finnish). Suom. Ayr. karja, 44, I77-I80.

Maijala K., r959. Mjölkboskapens livskraft som mål för aveln (In Swedish) Finl. Ayr. boskap, 44, 307-312.

Louca A., Legates J. E., 1968. Production losses in dairy cattle due to days open. J. Dairy Sci., 51, 573-583.

MaIJALA K., I964. Fertility as a breeding problem in artificially bred populations of dairy cattle. I. Registration and heritability of female fertility. Ann. Agric. Fenn., 3, Suppl., 3, I-94.

MaIJALA K., r966. Fruchtbarkeit und Erblichkeit. Züchtungskunde 38, 385-399.

VARO M., 1958. Über die Brauchbarkeit unserer Bullenwerte auf den verschiedenen Leistungsstufen. Acta Agr. Fenn., 93, 4, I-3I. 